\title{
SYNTACTIC COMPLEXITY IN EFL AND NATIVE LEARNERS' UNDERGRADUATE THESIS ABSTRACTS
}

\author{
Murniati* \\ English Language and Culture Department, Bunda Mulia University \\ Received on 29 September 2018 / Approved 15 October 2018
}

\begin{abstract}
This research aims to find syntactic complexity of the abstracts in the undergraduate thesis written down by university learners in Indonesia and the ones written down by native speakers of English. The characteristics of syntactic complexity produced by Indonesian learners and the learners who are the native speakers should also be analyzed. It is possible to extend the type of syntactic complexity found in academic texts. In the end, those extensions should be characterized the English language used by Indonesian learners. The data is gained through downloading the abstracts of the undergraduate thesis in the academic year of 20152016 from the UBM English Department alumni database. The data regarding the abstracts written down by the native speakers is downloaded from the reputable universities in The United States of America. After that, the data is analyzed by making used of the syntactic analyzer by $\mathrm{Lu} \& \mathrm{Ai}$ (2015). The results shows that the Indonesian learners tend to write more complex sentences and use subordination in the abstracts. The native speakers, on the other hands, tend to write longer sentences with longer T-Unit and clauses. They also tend to write complex nominal in the abstracts. The number of coordination used is similar between the ones written down by Indonesian learners and native speakers of English.
\end{abstract}

Keywords: syntactic complexity, syntactic structures, undergraduate thesis, Indonesian learners

\begin{abstract}
ABSTRAK
Penelitian ini bertujuan untuk menemukan kompleksitas leksikal dalam hal orisinalitas, kepadatan, kecanggihan, dan variasi abstrak dalam skripsi yang ditulis oleh mahasiswa di Indonesia dan yang ditulis oleh penutur asli bahasa Inggris. Karakteristik kompleksitas leksikal yang dihasilkan oleh pembelajar Indonesia dan pembelajar yang merupakan penutur asli juga harus dibandingkan. Diharapkan para mahasiswa Indonesia, khususnya mahasiswa Jurusan Bahasa Inggris dapat belajar dari hasil-hasil yang nantinya dapat membuat penggunaan kata leksikal mereka lebih mirip dengan penutur asli. Data penelitian ini diperoleh dengan cara mengunduh abstrak skripsi dari tahun akademik 2015-2016. Data kedua diperoleh dengan mengunduh abstrak dari situs web universitas terkemuka di Amerika Serikat. Data dianalisis dengan memanfaatkan penganalisis kompleksitas leksikal berbasis web oleh Lu \& Ai (2015). Hasil penelitian menunjukkan bahwa pelajar Indonesia cenderung menulis kalimat yang lebih kompleks dan menggunakan subordinasi di abstrak-abstraknya. Di lain pihak, penutur asli cenderung menulis kalimat yang lebih panjang dengan T-Unit dan klausa yang lebih panjang. Mereka juga cenderung menulis nominal kompleks dalam abstrak. Jumlah koordinasi yang digunakan mirip antara yang ditulis oleh pelajar Indonesia dan penutur asli bahasa Inggris.
\end{abstract}

Kata Kunci: kompleksitas leksikal, orisinalitas leksikal, kecanggihan leksikal, kepadatan leksikal, variasi leksikal

*Author(s) Correspondence:

E-mail: murniati@bundamulia.ac.id 


\section{INTRODUCTION}

\subsection{Background}

There have been many researches which discuss about the uniqueness of English used in several contexts in several places. The English usages in Non English speaking countries have widely recognized due to its role as a global language (Crystal, 2003). However, it must be admitted that the English language used by the native speakers of English, which is called as the inner circle (Kachru, 1989) is still being used as the standard English, especially in academic writing. As a result, the English used by the non-native speakers in academic writing is still being compared to the ones written down by the native speakers due to its appropriateness.

In relation to the English language used in the undergraduate thesis, an aspect that can be analyzed is about the syntactic structures and complexity. The term complexity as Biber \& Gray (2015) suggest, refers to the availability of dependent clause. A "simple" clause consists of a single subject, verb, and object. A "simple" phrase consists of a head and a determiner. An addition to those simple constructions can be called as complexity. In addition to the definition, Fang \& Schleppegrell (2008) argue that the length of clause and phrase can also determine the complexity. The longer the clause and phrase, the more complex they will be.

Syntactic structures in written academic texts, including the undergraduate theses, has got its own characteristics. In the level of clause, it is found out that finite adverbial clauses are not commonly found. Next, That-complement clauses are highly used in popular science academic text while non-finite complement clauses and finite relative clauses are used more often in humanities texts (Biber \& Gray, 2015). Regarding the syntactic complexity in the phrase level, the evidence shows that progressive verbs is decreasing over the past two centuries (Biber\& Gray, 2015) Next, it can be said that major grammatical complexities of writing relies on nouns and nominalizations (Fang, Schleppegrel, \& Cox, 2006).

There have been many results of researches talking about the comparison of both syntactic structures complexity produced by American or British learners who belong to the inner circle and learners from the outer or expanded circles. The differences ranged from the overuse of certain grammar complexity or, usually, less and inappropriate Syntactic complexity produced by the non-native speakers of English from both the outer and expanded circles. Tapper (2005) presents some evidences that Swedish EFL learners overuse the adverbial connectives compared to Native American English learners. On the other hands, there is also a research shows that Spanish learners use less syntactic complexity in terms of nominalization and clause combinations (Columbi, 2002). In the level of clauses, Iranian EFL Learners use less adjective clauses, than then the Native American English learners (Seifoori \& Fattahi, 2014). Moreover, Syntactic complexity is also related to proficiency. Iranian EFL learners with Higher English proficiency have produced similar Syntactic complexity to Native American English learners (Seifoori \& Fattahi, 2014).

The above researches show that syntactic structures complexity are commonly seen from the clausal complexity. Not until 2015 does when Biber \& Gray (2015) discusses phrasal complexity. They argue that phrasal complexity is more common than clausal complexity in academic writing that it gives characters to academic writing. In a more general term, they said that the syntactic complexity change actually talks about the phrasal complexity, not about the clausal complexity. Moreover, he also argues that "one of these alternative types of complexity involves the extensive use of embedded phrases than the clausal complexity". It is also such an unfortunate that some corpus based research regarding syntactic complexity is still not complete due to the lack of the phrasal complexity device tracker (Biber \& Gray, 2015).

\footnotetext{
*Author(s) Correspondence:

E-mail: murniati@bundamulia.ac.id
} 


\subsection{Research Questions}

The previous studies have indicated that little attention has been paid to the syntactic complexity, especially in academic texts. This present research is therefore aims to answer the following research questions.

1. What syntactic structures found in the abstracts of the undergraduate thesis written down by EFL learners and native speakers of English?

2. What syntactic complexity found in the abstracts of the undergraduate thesis written down by EFL learners and native speakers of English?

3. To what extent are they different?

a. What are the characteristics of the abstracts of the undergraduate thesis written down by EFL learners?

b. What are the characteristics of the abstracts of the undergraduate thesis written down by native speakers of English?

\subsection{Research Objectives}

The objective of this research is first, to determine the typical syntactic structures and complexity found in the abstracts of undergraduate thesis written down by EFL learners and native speakers of English. Next, it would also like to see characteristics of the abstracts of the undergraduate thesis written down by both EFL learners and native speakers of English.

\subsection{Significance of the Research}

It is expected that the results of this study will present a new or expanded classification of the syntactic structures and complexity commonly used in the academic text. It is later the undergraduate learners who can specifically choose one kind of phrase, such as the noun phrase, and analyze texts based on the results of this research.

\subsection{Scope and Limitation}

The scope of this research is syntactic structures and complexities found in 30 abstracts of undergraduate theses written by university learners studying in Universitas
Bunda Mulia in 2016-2017, where the researcher teaches. Other abstracts should be downloaded from reputable universities in The United States of America.

This research has also some limitations. Due to the access, the syntactic structures and complexity will only be analyzed from the abstracts of the undergraduate thesis. Moreover, due to the numbers of the university which has English Program, this research will cover 30 abstract from Universitas Bunda Mulia the 30 abstracts which are written down by the native speakers of English.

\section{THEORETICAL FRAMEWORK}

\subsection{Syntactic Structures and Complexity}

Corpus linguistics deals with how language is used in real-life contexts. The term "corpus" refers to the collection of words used in a natural usage of a language (Hunston, 2005). The fast growing technology allows people to create corpus software to analyze the language, especially English. People can see the frequency of word, differentiate between spoken and written language used, and the field where certain language is used by using that corpus software.

$\mathrm{Lu} \& \mathrm{Ai}$ (2015) has developed a syntactic analysis program called as L2 Syntactic Complexity Analyzer 3.3.3. The program can identify two measurements, they are (1) syntactic structure analyzer, and (2) syntactic complexity analyzer. The syntactic structures analyzer is measuring the word count $(\mathrm{W})$, the number of the sentence (S), the verb phrase (VP), the clause (C), the T-Unit (T), the dependent clause (DC), the complex T-Unit (CT), coordinate phrase (CP), and its complex nominal $(\mathrm{CN})$. Those syntactic structures are analyzing the texts which have not been put in phrase structures. The syntactic structures are usually being analyzed to predict the syntactic complexity of the texts.

The syntactic complexity analyzer is basically analyzing the phrase structures of each sentences found in the texts. They can basically measure fourteen categories. They can be seen in the table in the next page.

\footnotetext{
*Author(s) Correspondence:

E-mail: murniati@bundamulia.ac.id
} 


\begin{tabular}{|c|c|c|}
\hline Measure & Code & Definition \\
\hline $\begin{array}{l}\text { Type 1: Length of production unit } \\
\text { Mean length of clause } \\
\text { Mean length of sentence } \\
\text { Mean length of T-unit }\end{array}$ & $\begin{array}{l}\text { MLC } \\
\text { MLS } \\
\text { MLT }\end{array}$ & $\begin{array}{l}\text { \# of words / \# of clauses } \\
\text { \# of words / \# of sentences } \\
\text { \# of words / \# of T-units }\end{array}$ \\
\hline $\begin{array}{l}\text { Type 2: Sentence complexity } \\
\text { Sentence complexity ratio }\end{array}$ & $\mathrm{C} / \mathrm{S}$ & \# of clauses / \# of sentences \\
\hline $\begin{array}{l}\text { Type 3: Subordination } \\
\text { T-unit complexity ratio } \\
\text { Complex T-unit ratio } \\
\text { Dependent clause ratio } \\
\text { Dependent clauses per T-unit }\end{array}$ & $\begin{array}{l}\mathrm{C} / \mathrm{T} \\
\mathrm{CT} / \mathrm{T} \\
\mathrm{DC} / \mathrm{C} \\
\mathrm{DC} / \mathrm{T} \\
\end{array}$ & $\begin{array}{l}\text { \# of clauses / \# of T-units } \\
\text { \# of complex T-units / \# of T-units } \\
\text { \# of dependent clauses / \# of clauses } \\
\text { \# of dependent clauses / \# of T-units }\end{array}$ \\
\hline $\begin{array}{l}\text { Type 4: Coordination } \\
\text { Coordinate phrases per clause } \\
\text { Coordinate phrases per T-unit } \\
\text { Sentence coordination ratio }\end{array}$ & $\begin{array}{l}\mathrm{CP} / \mathrm{C} \\
\mathrm{CP} / \mathrm{T} \\
\mathrm{T} / \mathrm{S}\end{array}$ & $\begin{array}{l}\# \text { of coordinate phrases / \# of clauses } \\
\# \text { of coordinate phrases / \# of T-units } \\
\# \text { of T-units / \# of sentences }\end{array}$ \\
\hline $\begin{array}{l}\text { Type 5: Particular structures } \\
\text { Complex nominals per clause } \\
\text { Complex nominals per T-unit } \\
\text { Verb phrases per T-unit }\end{array}$ & $\begin{array}{l}\mathrm{CN} / \mathrm{C} \\
\mathrm{CN} / \mathrm{T} \\
\mathrm{VP} / \mathrm{T}\end{array}$ & $\begin{array}{l}\text { \# of complex nominals / \# of clauses } \\
\# \text { of complex nominals / \# of T-units } \\
\text { \# of verb phrases / \# of T-units }\end{array}$ \\
\hline
\end{tabular}

Table 3.1. Syntactic complexity measurement

As can be seen above, there are five different measurement in order to identify the syntactic complexity of a text. of the the measurement is calculated based of the evidence of word, phrase, clause, sentences and T-Unit. T-unit itself is defined as "the shortest unit into which a piece of discourse can be cut without leaving any sentence fragments as residue" (Hunt, cited in BardoviHarlig, 1992). To make it easy, look at the examples below.

(1) The boy is clever and he has just won a spelling bee competition

(2) The boy who is clever has just won a spelling bee competition.

Sentence (1) above contain 2 (two) subjects and verbs which are connected by "and". It is considered as two T-units. On the other hands, sentence (2) has one subject and verb and one dependent clause. It is, therefore, considered as one T-unit.

The first measurement is the length of the production unit. The mean length of the sentences, the clauses and T-unit are measured. The second is the number of clauses found in the sentences after being analyzed in the phrase structures. The more complex the sentence, the more clauses are found in the sentence. The third is measuring the subordination found in the text. It can be found by measuring the number of clauses in the Tunits, the complex T-Units in each T-units and the number of dependent clauses in both clauses and T-Units. The fourth measurement is about the coordination. The texts are analyzed in accordance to the number of independent clause found in both T-Unit and clauses. The last is about the particular structures. It is basically measuring the complex nominal and verb phrases in both the clauses and T-Units.

\subsection{Phrasal Complexity as a Part of Syntactic Complexity}

A sentence is not just a group of words; it can be broken down into several constituent. This constituent is called as a phrase which can consist of one or more than one words. If it is one, it must be the head and if it consists of more than words, it must be the

*Author(s) Correspondence:

E-mail: murniati@bundamulia.ac.id 
head and the determiner, the head and the modifier, the head and the complement, or the combination of all of them. Unlike a clause, a phrase is characterized by the substitution. It means that those many words in a phrase can be substituted by a single head word. In addition, a phrase can also be moved as a unit. Last, a phrase can be "embedded at different levels and in some cases a given structure can have more than one interpretation" (Biber, Johansson, Leech, Conrad, \& Finegan, 1999).

The evidence that shows a phrase can have multi interpretation makes it a complex phrase. In addition, a phrase can be categorized as complex if it contains more than four words (Biber, Johansson, Leech, Conrad, \& Finegan, 1999).

In relation to part of speech, there are five kinds of English phrases; they are noun, verb, adjective, adverb, and prepositional phrases.

\section{A. Noun Phrase}

A noun phrase consists of a noun as the head. It can be accompanied by determiners which specify the reference of the noun and modifiers which describe or classify the noun. The noun can also be followed by a complement which usually takes the form of that-clause. Below is the example of a noun which is followed by that-clause in an academic text:

"The popular assumption that language simply serves to communicate "thoughts" or "ideas" is too simplistic" (Biber, Johansson, Leech, Conrad, \& Finegan, 1999).

The above example shows the head noun "assumption" followed by a complement thatclause "that language simply serves to communicate "thoughts" or "ideas".

The noun phrase has several syntactic roles. The most common ones are as (1) subject, (2) direct object, (3) indirect object, (4) prepositional object, and (5) complement of preposition. Besides those most common roles, a noun phrase also has other syntactic roles. They are (6) subject predicative, (7) object predicative, (8) adverbial, (9) premodifier of noun, (10) apposition, and (11) premodifier in adjective or adverb phrase (Biber, Johansson, Leech, Conrad, \& Finegan, 1999).

Regarding the complex noun phrase, Biber, Johansson, Leech, Conrad, \& Finegan, (1999) also say that it could be "split up" under circumstances, such as in the following example: "In this chapter a description will be given of the food assistance programs that address the needs of a family".

\section{B. Verb Phrase}

Verb phrases contain of a lexical verb as the main verb which could be accompanied by one or more auxiliaries. The verb phrase can be both finite and non-finite. The non-finite verb phrase does not usually contain "specification of tense and modality"; as a result, it has fewer possibilities of variations, such as "have caught". As for the syntactic role, the verb phrase usually serves as the "central clause elements". Both finite and non-finite verb phrase have the same role. Similar to noun phrase, the verb phrase might also discontinuous, such as in "The current year has definitely started well (Biber, Johansson, Leech, Conrad, \& Finegan, 1999).

\section{Adjective Phrase}

An adjective phrase contains an adjective as the head and could be accompanied by modifiers in the form of word, phrase, and clause. It also has several syntactic roles. The two most common roles are as (1) premodifier of nouns, and (2) subject predicative. Other roles are as (3) post modifier of nouns, and (4) object predicative. An adjective phrase has also recognized the discontinues adjective clause, such as in: "You couldn't have a better name than that" It can be seen that the two adjective phrase "better" and "than that" is separated by a noun "name" (Biber et. al, 1999).

\section{Adverb Phrase}

An adverb phrase contains an adverb as the head which is optionally followed by the modifiers in the form of word, phrase, and clause. The two most common syntactic roles of adverb phrases are (1) modifier in adjective

\footnotetext{
*Author(s) Correspondence:

E-mail: murniati@bundamulia.ac.id
} 
or adverb phrase, and (2) adverbial in clause level. Other syntactic roles are (3) pre- and postmodifier in noun phrase, (4) complement of preposition, and (5) premodifier in prepositional phrase (Biber, Johansson, Leech, Conrad, \& Finegan, 1999).

\section{E. Prepositional Phrase}

A prepositional phrase consists of a preposition and a complement. A prepositional phrase can be preceded by adverbial particles and other modifying elements. The syntactic roles of a prepositional phrases are as (1) adverbial on the clause level, (2) postmodifier and complement of noun, (3) premodifier of noun, and (5) complement of adjectives (Biber, Johansson, Leech, Conrad, \& Finegan, 1999).

\section{RESEARCH METHODOLOGY}

\subsection{Source of Data}

The Data is gained from the abstracts of the undergraduate thesis written by Bunda Mulia University learners studying at English Department. The abstracts written down in the academic year of 2015-2017 should be analyzed. Next, the abstracts which are written down by native speakers of English should be downloaded from several reputable universities and Schools which first language is English. The abstracts should also be written down between 2015 to 2017 .

\subsection{Data Collection Procedures}

The data is collected one by one, starting from selecting and downloading the research articles written down by Bunda Mulia University learners majoring in English. Next, the data is saved in plain texts so that it can be uploaded into corpus application later on. After that, abstracts from Oxford University are also downloaded and saved in plain texts. In short, all of them can be seen in the figure below.

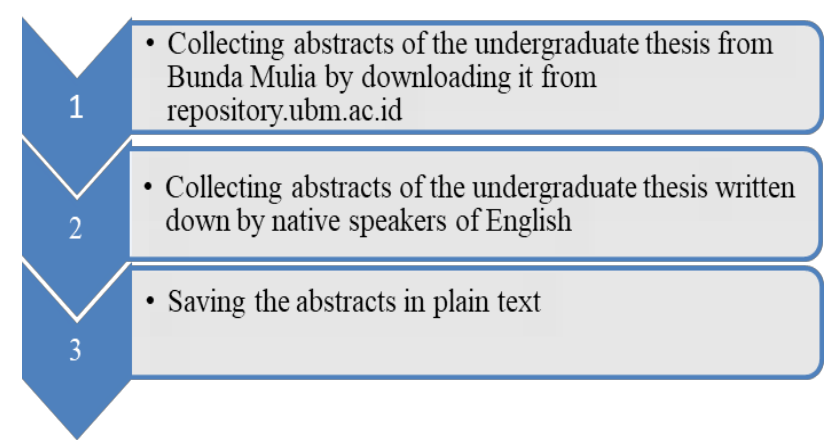

Figure 3.1. Data collection procedures

\subsection{Data Analysis Procedure}

In order to answer research questions, several steps are conducted. It can be seen in the figure below.

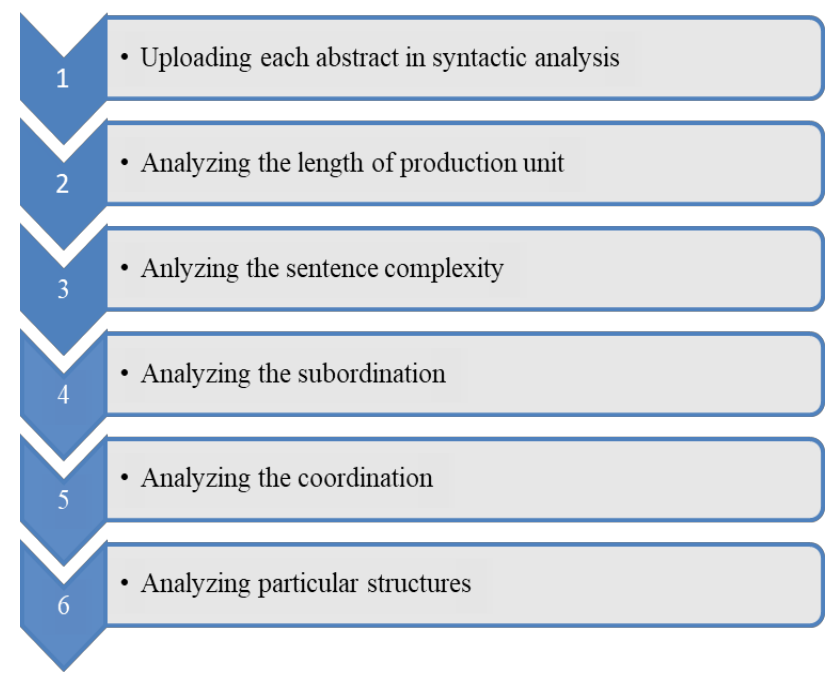

Figure 3.2. Data Analysis Procedure

As can be seen above, after all of the data is uploading, length of production unit, the sentence complexity, the subordination, coordination, and particular structures are analyzed. Later, it could be concluded whether the abstracts are complex or not in terms of the syntactical units.

\section{FINDINGS AND DISCUSSION}

\subsection{Syntactic Complexity in the Abstracts}

Since syntactic complexity can be characterized by its structures and indices, this research is also presented by those two parts.

\footnotetext{
*Author(s) Correspondence:

E-mail: murniati@bundamulia.ac.id
} 
One is in accordance to the syntactic structures, and the other by its syntactic complexity indices. The syntactic structures can be concluded from the word count (W), the number of the sentence $(\mathrm{S})$, the verb phrase (VP), the clause (C), the T-Unit (T), the dependent clause (DC), the complex T-Unit (CT), coordinate phrase (CP), and its complex nominal $(\mathrm{CN})$. The syntactic complexity itself are divided into several indices, namely the mean length of the sentence (MLS), the mean length of the T-unit (MLT), the mean length of the clause (MLC), the clause per sentence $(\mathrm{C} / \mathrm{S})$, verb phrase per T-Unit (VP/T), clause per $\mathrm{T}$-unit $(\mathrm{C} / \mathrm{T})$, dependent clause per clause
(DC/C), dependent clause per T-unit (DC/T), T-unit per sentence (T/S), Complex T-unit ratio $(\mathrm{CT} / \mathrm{T})$, coordinate phrase per $\mathrm{T}$-unit $(\mathrm{CP} / \mathrm{T})$, coordinate phrase per clause $(\mathrm{CP} / \mathrm{C})$, complex nominal per $\mathrm{T}$-unit $(\mathrm{CN} / \mathrm{T})$, complex nominal per clause $(\mathrm{CN} / \mathrm{C})$.

\subsubsection{Syntactic Structures of the abstract written down by Indonesian learners}

The table below shows the syntactic structures written down by Indonesian learners. There are thirty of them.

\begin{tabular}{|c|c|c|c|c|c|c|c|c|c|}
\hline $\begin{array}{c}\text { FILE } \\
\text { NAME }\end{array}$ & $\mathbf{W}$ & $\mathbf{S}$ & VP & C & $\mathbf{T}$ & DC & CT & $\mathbf{C P}$ & $\mathbf{C N}$ \\
\hline Student 1 & 3907 & 97 & 96 & 93 & 77 & 12 & 7 & 11 & 118 \\
\hline Student 2 & 3529 & 81 & 93 & 88 & 59 & 20 & 8 & 9 & 103 \\
\hline Student 3 & 3984 & 95 & 97 & 93 & 72 & 16 & 9 & 10 & 117 \\
\hline Student 4 & 3396 & 76 & 77 & 75 & 60 & 14 & 6 & 8 & 87 \\
\hline Student 5 & 3985 & 97 & 96 & 96 & 78 & 15 & 9 & 11 & 117 \\
\hline Student 6 & 3538 & 86 & 101 & 95 & 72 & 19 & 9 & 11 & 107 \\
\hline Student 7 & 3319 & 85 & 95 & 89 & 68 & 17 & 9 & 7 & 109 \\
\hline Student 8 & 3496 & 87 & 94 & 88 & 66 & 21 & 6 & 11 & 118 \\
\hline Student 9 & 3687 & 89 & 122 & 112 & 73 & 24 & 11 & 9 & 120 \\
\hline Student 10 & 3938 & 99 & 98 & 93 & 74 & 12 & 6 & 11 & 122 \\
\hline Student 11 & 3780 & 92 & 95 & 94 & 74 & 19 & 9 & 3 & 120 \\
\hline Student 12 & 4018 & 103 & 107 & 97 & 81 & 16 & 12 & 8 & 130 \\
\hline Student 13 & 4012 & 92 & 88 & 84 & 66 & 14 & 6 & 8 & 107 \\
\hline Student 14 & 3410 & 92 & 105 & 98 & 78 & 15 & 5 & 4 & 110 \\
\hline Student 15 & 3987 & 103 & 96 & 93 & 75 & 16 & 7 & 12 & 120 \\
\hline Student 16 & 4036 & 89 & 87 & 83 & 67 & 11 & 6 & 9 & 105 \\
\hline Student 17 & 3578 & 99 & 113 & 112 & 84 & 19 & 12 & 14 & 151 \\
\hline Student 18 & 3619 & 96 & 93 & 92 & 72 & 17 & 9 & 11 & 117 \\
\hline Student 19 & 3677 & 92 & 102 & 95 & 74 & 20 & 5 & 9 & 128 \\
\hline
\end{tabular}

*Author(s) Correspondence:

E-mail: murniati@bundamulia.ac.id 


\begin{tabular}{|l|c|c|c|c|c|c|c|c|c|}
\hline \hline Student 20 & 6671 & 121 & 133 & 120 & 94 & 25 & 13 & 16 & 149 \\
\hline Student 21 & 4018 & 101 & 113 & 104 & 83 & 16 & 10 & 11 & 133 \\
\hline Student 22 & 3707 & 87 & 94 & 85 & 66 & 20 & 7 & 5 & 103 \\
\hline Student 23 & 3841 & 77 & 90 & 77 & 60 & 15 & 6 & 8 & 106 \\
\hline Student 24 & 3876 & 90 & 97 & 93 & 67 & 16 & 8 & 12 & 117 \\
\hline Student 25 & 3735 & 93 & 117 & 114 & 74 & 31 & 12 & 10 & 147 \\
\hline Student 26 & 3914 & 94 & 106 & 97 & 73 & 15 & 10 & 11 & 127 \\
\hline Student 27 & 3485 & 90 & 100 & 100 & 72 & 27 & 11 & 14 & 133 \\
\hline Student 28 & 3672 & 94 & 103 & 90 & 76 & 12 & 6 & 13 & 99 \\
\hline Student 29 & 3559 & 96 & 108 & 101 & 73 & 26 & 10 & 6 & 124 \\
\hline Student 30 & 3562 & 93 & 102 & 95 & 70 & 21 & 9 & 7 & 122 \\
\hline Average & $\mathbf{3 8 3 1 . 2}$ & $\mathbf{9 2 . 9}$ & $\mathbf{1 0 0 . 6}$ & $\mathbf{9 4 . 9}$ & $\mathbf{7 2 . 6}$ & $\mathbf{1 8 . 0}$ & $\mathbf{8 . 4}$ & $\mathbf{9 . 6}$ & $\mathbf{1 1 8 . 9}$ \\
\hline
\end{tabular}

Table 4.1. Syntactic structures of the abstract written down by Indonesian learners.

As can be seen in the table above, the average number of the sentence is 92.9 sentences which is written down in the average of 3831.2 words. There are 100.6 verb phrases in those 92 sentences. It means that some sentences have more than one verb phrases. On the other hands, there are 94.9 clauses in those 92.9 sentences. The T-unit or minimum terminable unit is only 72.6 . It shows that the sentences produced by Indonesian learners are not really effective. Some of them can be combined into more complex sentences. This conclusion is supported by the average number of dependent clause which reaches 18 . Comparing to the number of sentences, this number is really low. In addition, the complex $\mathrm{T}$ unit is only 8.4. It is even lower than the average number of the dependent clauses. It might happen since the average number of the coordinate phrase is only 9.6. The complex nominal is about 118.9. It means that the learners mostly use phrases than clauses in the sentences.

\subsubsection{Syntactic Structures of the abstract written down by Native Speakers}

The table below shows the words, sentences, verb phrases, clauses, T-unit, dependent clauses, Complex T-Unit, coordinate phrases and complex nominal written down by the native learners in their undergraduate thesis.

\begin{tabular}{|l|c|c|c|c|c|c|c|c|c|}
\hline $\begin{array}{c}\text { FILE } \\
\text { NAME }\end{array}$ & W & S & VP & C & T & DC & CT & CP & CN \\
\hline Native 1 & 4171 & 97 & 115 & 105 & 78 & 22 & 11 & 8 & 149 \\
\hline Native 2 & 4187 & 99 & 101 & 94 & 78 & 13 & 8 & 11 & 129 \\
\hline
\end{tabular}

*Author(s) Correspondence:

E-mail: murniati@bundamulia.ac.id 


\begin{tabular}{|c|c|c|c|c|c|c|c|c|c|}
\hline Native 3 & 3913 & 99 & 110 & 99 & 73 & 22 & 11 & 16 & 143 \\
\hline Native 4 & 3889 & 98 & 93 & 88 & 70 & 14 & 6 & 9 & 128 \\
\hline Native 5 & 3891 & 99 & 100 & 96 & 74 & 19 & 9 & 10 & 132 \\
\hline Native 6 & 3890 & 93 & 96 & 90 & 72 & 18 & 10 & 11 & 133 \\
\hline Native 7 & 4055 & 95 & 101 & 93 & 74 & 16 & 9 & 10 & 110 \\
\hline Native 8 & 4004 & 96 & 96 & 87 & 72 & 14 & 6 & 10 & 133 \\
\hline Native 9 & 4152 & 101 & 105 & 99 & 82 & 15 & 6 & 8 & 131 \\
\hline Native 10 & 4186 & 103 & 106 & 98 & 77 & 15 & 9 & 12 & 138 \\
\hline Native 11 & 3848 & 109 & 121 & 104 & 82 & 20 & 10 & 13 & 157 \\
\hline Native 12 & 4036 & 102 & 105 & 99 & 82 & 15 & 9 & 12 & 144 \\
\hline Native 13 & 4061 & 100 & 86 & 85 & 71 & 11 & 5 & 12 & 121 \\
\hline Native 14 & 4066 & 98 & 104 & 98 & 78 & 16 & 10 & 8 & 130 \\
\hline Native 15 & 4324 & 99 & 110 & 105 & 81 & 14 & 8 & 10 & 117 \\
\hline Native 16 & 4297 & 99 & 104 & 98 & 80 & 14 & 8 & 11 & 126 \\
\hline Native 17 & 4074 & 100 & 95 & 95 & 75 & 16 & 8 & 13 & 136 \\
\hline Native 18 & 4282 & 97 & 107 & 100 & 75 & 21 & 11 & 12 & 131 \\
\hline Native 19 & 4086 & 92 & 97 & 91 & 72 & 15 & 7 & 14 & 117 \\
\hline Native 20 & 3873 & 95 & 96 & 96 & 77 & 17 & 8 & 9 & 129 \\
\hline Native 21 & 4136 & 96 & 101 & 97 & 77 & 16 & 8 & 10 & 122 \\
\hline Native 22 & 4121 & 88 & 92 & 84 & 68 & 13 & 10 & 8 & 134 \\
\hline Native 23 & 4039 & 101 & 99 & 98 & 81 & 15 & 7 & 8 & 133 \\
\hline Native 24 & 3941 & 91 & 93 & 90 & 72 & 17 & 9 & 11 & 134 \\
\hline Native 25 & 4058 & 91 & 97 & 92 & 73 & 13 & 7 & 14 & 119 \\
\hline Native 26 & 3973 & 101 & 88 & 86 & 68 & 14 & 6 & 10 & 133 \\
\hline Native 27 & 4053 & 94 & 100 & 90 & 75 & 12 & 8 & 9 & 115 \\
\hline Native 28 & 4067 & 92 & 92 & 86 & 68 & 14 & 8 & 9 & 109 \\
\hline Native 29 & 4212 & 90 & 91 & 85 & 67 & 14 & 9 & 11 & 121 \\
\hline Native 30 & 3559 & 96 & 108 & 101 & 73 & 26 & 10 & 6 & 124 \\
\hline Average & 4048.13 & 97.03 & 100.30 & 94.30 & 74.83 & 16.03 & 8.37 & 10.50 & 129.27 \\
\hline
\end{tabular}

Table 4.2. Syntactic structures of the abstract written down by native learners

*Author(s) Correspondence:

E-mail: murniati@bundamulia.ac.id 
As can be seen above, the average number of sentences is about 97. Those sentences are considered as effective sentences which have the high number of syntactic structures. First, the number of the verb phrase is higher than the number of the sentences. The average number of clauses also closes to the average number of sentences. Next, the T unit is 74.83 which mean that some sentences can actually be combined into more complex sentences. It is also supported by the number of dependent clauses which reach 18 . In addition, the average number of complex $\mathrm{T}$ Unit is also low; it is only 8.4. The coordinate phrase is also low which support the first conclusion that most of the sentences are not complex. Finally, the complex nominal number reaches about 118 . It shows that the sentences contain more phrases than clauses.

\subsubsection{The Different Syntactic Structures of the Abstract Written Down by Indonesian and Native Speakers}

After discussing the results of the syntactic structures found in the abstracts written down by the Indonesian and native learners, the overall results of both of them can be seen in the table below.

\begin{tabular}{|c|l|c|c|}
\hline No & \multicolumn{1}{|c|}{ Structures } & Indonesian Learners & Native Speakers \\
\hline 1. & Words & 4048.13 & $\mathbf{3 8 3 1 . 2}$ \\
\hline 2. & Sentences & 97.03 & $\mathbf{9 2 . 9}$ \\
\hline 3. & Verb Phrase & 100.30 & $\mathbf{1 0 0 . 6}$ \\
\hline 4. & Clause & 94.30 & $\mathbf{9 4 . 9}$ \\
\hline 5. & T-Unit & 74.83 & $\mathbf{7 2 . 6}$ \\
\hline 6. & Dependent Clause & 16.03 & $\mathbf{1 8 . 0}$ \\
\hline 7. & Complex T-Unit & 8.37 & $\mathbf{8 . 4}$ \\
\hline 8. & Coordinate phrase & 10.5 & $\mathbf{9 . 6}$ \\
\hline 9. & Complex Nominal & 129.27 & $\mathbf{1 1 8 . 9}$ \\
\hline
\end{tabular}

Table 4.3. The average number of syntactic structures of the abstract written down by both Indonesian and native speakers

As can be seen from the tables, the results are not really different from one to another. It just can be seen that the native speakers tend to write more complex sentences which are marked by the number of dependent clauses found. On the other hands, the Indonesian learners tend to use more complex nominal than the native speakers.

\subsection{The Syntactic Complexity Indices}

In order to indicate the syntactic complexity indices, there are several measurements which in general are divided into five types. Type 1 is regarding the length of production unit. It is divided into (1) Mean length of clause, (2) Mean length of sentence, and (3) Mean length of T-unit. Type 2 is about the sentence complexity. It is divided into (1) Sentence complexity ratio. Type 3 is in relation to the subordination. It is divided into (1) T-unit complexity ratio, (2) Complex Tunit ratio, (3) Dependent clause ratio, and (4) Dependent clauses per T-unit. Type 4 is about the coordination. There are the sub parts: (1) Coordinate phrases per clause, (2) Coordinate phrases per T-unit, and (3) Sentence coordination ratio. The last type, which is type 5 is in relation to particular structures. It is divided into (1) Complex nominal per clause, (2) Complex nominal per T-unit, and (3) Verb phrases per T-unit.

*Author(s) Correspondence:

E-mail: murniati@bundamulia.ac.id 


\subsubsection{The Length of Production Unit}

The table below shows the length of the production unit produced by both the Indonesian and native learners.

\begin{tabular}{|c|c|c|c|c|c|c|}
\hline \multirow{2}{*}{ No } & \multicolumn{2}{|c|}{ MLS } & \multicolumn{2}{c|}{ MLT } & \multicolumn{2}{c|}{ MLC } \\
\cline { 2 - 7 } & Indonesian & Native & Indonesian & Native & Indonesian & Native \\
\hline 1 & 402,784 & 430,000 & 507,403 & 534,744 & 420,108 & 397,238 \\
\hline 2 & 435,679 & 422,929 & 598,136 & 536,795 & 401,023 & 445,426 \\
\hline 3 & 419,368 & 395,253 & 553,333 & 536,027 & 428,387 & 395,253 \\
\hline 4 & 446,842 & 396,837 & 566,000 & 555,571 & 452,800 & 441,932 \\
\hline 5 & 410,825 & 393,030 & 510,897 & 525,811 & 415,104 & 405,312 \\
\hline 6 & 411,395 & 418,280 & 491,389 & 540,278 & 372,421 & 432,222 \\
\hline 7 & 390,471 & 426,842 & 488,088 & 547,973 & 372,921 & 436,022 \\
\hline 8 & 401,839 & 417,083 & 529,697 & 556,111 & 397,273 & 460,230 \\
\hline 9 & 414,270 & 411,089 & 505,068 & 506,341 & 329,196 & 419,394 \\
\hline 10 & 397,778 & 406,408 & 532,162 & 543,636 & 423,441 & 427,143 \\
\hline 11 & 410,870 & 353,028 & 510,811 & 469,268 & 402,128 & 370,000 \\
\hline 12 & 390,097 & 395,686 & 496,049 & 492,195 & 414,227 & 407,677 \\
\hline 13 & 436,087 & 406,100 & 607,879 & 571,972 & 477,619 & 477,765 \\
\hline 14 & 370,652 & 414,898 & 437,179 & 521,282 & 347,959 & 414,898 \\
\hline 15 & 387,087 & 436,768 & 531,600 & 533,827 & 428,710 & 411,810 \\
\hline 16 & 453,483 & 434,040 & 602,388 & 537,125 & 486,265 & 438,469 \\
\hline 17 & 361,414 & 407,400 & 425,952 & 543,200 & 319,464 & 428,842 \\
\hline 18 & 376,979 & 441,443 & 502,639 & 570,933 & 393,370 & 428,200 \\
\hline 19 & 399,674 & 444,130 & 496,892 & 567,500 & 387,053 & 449,011 \\
\hline 20 & 551,322 & 407,684 & 709,681 & 502,987 & 555,917 & 403,438 \\
\hline 21 & 397,822 & 430,833 & 484,096 & 537,143 & 386,346 & 426,392 \\
\hline 22 & 426,092 & 468,295 & 561,667 & 606,029 & 436,118 & 490,595 \\
\hline 23 & 498,831 & 399,901 & 640,167 & 498,642 & 498,831 & 412,143 \\
\hline
\end{tabular}

*Author(s) Correspondence:

E-mail: murniati@bundamulia.ac.id 


\begin{tabular}{|c|c|c|c|c|c|c|}
\cline { 3 - 7 } 24 & 430,667 & 433,077 & 578,507 & 547,361 & 416,774 & 437,889 \\
\hline 25 & 401,613 & 445,934 & 504,730 & 555,890 & 327,632 & 441,087 \\
\hline 26 & 416,383 & 393,366 & 536,164 & 584,265 & 403,505 & 461,977 \\
\hline 27 & 387,222 & 431,170 & 484,028 & 540,400 & 348,500 & 450,333 \\
\hline 28 & 390,638 & 442,065 & 483,158 & 598,088 & 408,000 & 472,907 \\
\hline 29 & 370,729 & 468,000 & 487,534 & 628,657 & 352,376 & 495,529 \\
\hline 30 & 383,011 & 370,729 & 508,857 & 487,534 & 374,947 & 352,376 \\
\hline Av & $\mathbf{4 1 2 , 3 9 7 . 4 7}$ & $\mathbf{4 1 8 , 0 7 7}$ & $\mathbf{5 2 9 , 0 7 1 . 7 0}$ & $\mathbf{5 4 2 , 5 8 6}$ & $\mathbf{4 0 5 , 9 4 7 . 1 7}$ & $\mathbf{4 3 1 , 0 5 0}$ \\
\hline
\end{tabular}

Table 4.4. The length of production unit

As can be seen in the table above, the (1) Mean length of clause, (2) Mean length of sentence, and (3) Mean length of T-unit written down by the native speakers are slightly higher than the ones written down by the Indonesian learners. Regarding the mean length of the clause, the native speakers write longer clauses than the Indonesian learners. Considering that the number of words and sentences written down by the Indonesian learners are higher, it can be concluded that in terms of the length of the production unit, the native speakers write a more syntactic complex texts.

\subsubsection{Sentence Complexity}

The sentence complexity ratio written down by both the Indonesian and native learners in their abstracts can be seen in the table below.

\begin{tabular}{|c|c|c|}
\hline \multirow{2}{*}{ No } & \multicolumn{2}{|c|}{ CS } \\
\cline { 2 - 3 } & Indonesian & Native \\
\hline 1 & 6.65833 & 10,825 \\
\hline 2 & 10,864 & 6.59375 \\
\hline 3 & 6.79792 & 10,000 \\
\hline 4 & 6.85278 & 6.23611 \\
\hline 5 & 6.87292 & 6.73403 \\
\hline 6 & 11,047 & 6.72014 \\
\hline 7 & 10,471 & 6.79792 \\
\hline 8 & 10,115 & 6.29306 \\
\hline 9 & 12,584 & 6.80694 \\
\hline
\end{tabular}

*Author(s) Correspondence:

E-mail: murniati@bundamulia.ac.id 


\begin{tabular}{|c|c|c|}
\hline 10 & 6.52361 & 6.60764 \\
\hline 11 & 10,217 & 6.62569 \\
\hline 12 & 6.53958 & 6.74028 \\
\hline 13 & 6.34028 & 5.90278 \\
\hline 14 & 10,652 & 10,000 \\
\hline 15 & 6.27014 & 10,606 \\
\hline 16 & 6.47639 & 6.87431 \\
\hline 17 & 11,313 & 6.59722 \\
\hline 18 & 6.65486 & 10,309 \\
\hline 19 & 10,326 & 6.86875 \\
\hline 20 & 6.88681 & 10,105 \\
\hline 21 & 10,297 & 10,104 \\
\hline 22 & 6.78472 & 6.62847 \\
\hline 23 & 10,000 & 6.73819 \\
\hline 24 & 10,333 & 6.86806 \\
\hline 25 & 12,258 & 10,110 \\
\hline 26 & 10,319 & 5.91319 \\
\hline 27 & 11,111 & 6.64861 \\
\hline 28 & 6.64861 & 6.49167 \\
\hline 29 & 10,521 & 6.55833 \\
\hline 30 & 10,215 & 10,521 \\
\hline Average & $6,090.98$ & 3,091 \\
\hline
\end{tabular}

Table 4.5. Sentence complexity

The table shows that the ratio of the sentence complexity in the Indonesian learners is much higher than the ones in the native learners. It means that the average number of clauses per sentence in the undergraduate thesis written down by the Indonesian learners is really high. It might happen since Indonesian learners usually use passive voice in academic writing, including in the abstracts.

\subsubsection{Subordination}

As mentioned earlier, subordination is divided into It is divided into (1) T-unit complexity ratio which defines clauses per unit, (2) complex T-unit ratio which calculates complex T-unit per T-unit, (3) Dependent clause ratio which talk about dependent clause per clause, and (4) Dependent clauses per Tunit. The results of the subordination written

*Author(s) Correspondence:

E-mail: murniati@bundamulia.ac.id 
down by both Indonesian and native learners

can be seen in the table below.

\begin{tabular}{|c|c|c|c|c|c|c|c|c|}
\hline \multirow{2}{*}{ No } & \multicolumn{2}{|c|}{$\mathrm{C} / \mathrm{T}$} & \multicolumn{2}{|c|}{ CT/T } & \multicolumn{2}{|c|}{ DC/C } & \multicolumn{2}{|c|}{ DC/T } \\
\hline & I & $\mathbf{N}$ & I & $\mathbf{N}$ & I & $\mathbf{N}$ & I & $\mathbf{N}$ \\
\hline 1 & 12,078 & 13,462 & 0.63 & 0.97917 & 0.90 & 1.45486 & 1.08 & 1.95903 \\
\hline 2 & 14,915 & 12,051 & 0.94 & 0.7125 & 1.58 & 0.96042 & 2.35 & 1.15764 \\
\hline 3 & 12,917 & 13,562 & 0.87 & 1.04653 & 1.19 & 1.54306 & 1.54 & 2.09306 \\
\hline 4 & 12,500 & 12,571 & 0.69 & 0.59514 & 1.30 & 1.10486 & 1.62 & 1.38889 \\
\hline 5 & 12,308 & 12,973 & 0.80 & 0.84444 & 1.08 & 1.37431 & 1.34 & 1.78333 \\
\hline 6 & 13,194 & 12,500 & 0.87 & 0.96458 & 1.39 & 1.38889 & 1.83 & 1.73611 \\
\hline 7 & 13,088 & 12,568 & 0.92 & 0.84444 & 1.33 & 1.19444 & 1.74 & 1.50139 \\
\hline 8 & 13,333 & 12,083 & 0.63 & 0.57847 & 1.66 & 1.11736 & 2.21 & 1.35 \\
\hline 9 & 15,342 & 12,073 & 1.05 & 0.50833 & 1.49 & 1.05208 & 2.28 & 1.27014 \\
\hline 10 & 12,568 & 12,727 & 0.56 & 0.81181 & 0.90 & 1.06319 & 1.13 & 1.35278 \\
\hline 11 & 12,703 & 12,683 & 0.84 & 0.84722 & 1.40 & 1.33542 & 1.78 & 1.69375 \\
\hline 12 & 11,975 & 12,073 & 1.03 & 0.7625 & 1.15 & 1.05208 & 1.37 & 1.27014 \\
\hline 13 & 12,727 & 11,972 & 0.63 & 0.48889 & 1.16 & 0.89861 & 1.47 & 1.07569 \\
\hline 14 & 12,564 & 12,564 & 0.45 & 0.89028 & 1.06 & 1.13403 & 1.34 & 1.42431 \\
\hline 15 & 12,400 & 12,963 & 0.65 & 0.68611 & 1.19 & 0.92569 & 1.48 & 1.2 \\
\hline 16 & 12,388 & 12,250 & 0.62 & 0.69444 & 0.92 & 0.99236 & 1.14 & 1.21528 \\
\hline 17 & 13,333 & 12,667 & 0.99 & 0.74097 & 1.18 & 1.16944 & 1.57 & 1.48125 \\
\hline 18 & 12,778 & 13,333 & 0.87 & 1.01875 & 1.28 & 1.45833 & 1.64 & 1.94444 \\
\hline 19 & 12,838 & 12,639 & 0.47 & 0.675 & 1.46 & 1.14444 & 1.88 & 1.44653 \\
\hline 20 & 12,766 & 12,468 & 0.96 & 0.72153 & 1.45 & 1.22986 & 1.85 & 1.53333 \\
\hline 21 & 12,530 & 12,597 & 0.84 & 0.72153 & 1.07 & 1.14514 & 1.34 & 1.44306 \\
\hline 22 & 12,879 & 12,353 & 0.74 & 1.02153 & 1.63 & 1.075 & 2.10 & 1.32778 \\
\hline 23 & 12,833 & 12,099 & 0.69 & 0.6 & 1.35 & 1.06319 & 1.74 & 1.28611 \\
\hline 24 & 13,881 & 12,500 & 0.83 & 0.86806 & 1.19 & 1.31181 & 1.66 & 1.63958 \\
\hline 25 & 15,405 & 12,603 & 1.13 & 0.66597 & 1.89 & 0.98125 & 2.91 & 1.23681 \\
\hline 26 & 13,288 & 12,647 & 0.95 & 0.6125 & 1.07 & 1.13056 & 1.43 & 1.42986 \\
\hline
\end{tabular}

*Author(s) Correspondence:

E-mail: murniati@bundamulia.ac.id 


\begin{tabular}{|c|c|c|c|c|c|c|c|c|}
\hline & 13,889 & 12,000 & 1.06 & 0.74097 & 1.88 & 0.92569 & 2.60 & 1.11111 \\
\hline 28 & 11,842 & 12,647 & 0.55 & 0.81667 & 0.93 & 1.13056 & 1.10 & 1.42986 \\
\hline 29 & 13,836 & 12,687 & 0.95 & 0.93264 & 1.79 & 1.14375 & 2.47 & 1.45139 \\
\hline 30 & 13,571 & 13,836 & 0.89 & 0.95139 & 1.54 & 1.7875 & 2.08 & 2.47361 \\
\hline Av & $13,088.97$ & 12,605 & 0.80 & 0.77808 & 1.31 & 1.17627 & 1.74 & 1.49021 \\
\hline
\end{tabular}

Table 4.6. Subordination

As the table suggests, the Indonesian learners tend to write more clause in each unit. As a result, the number of complex T-unit in each T-unit is also higher. Next, It can also be seen in table that the number of dependent clauses both per T-unit and per clause used by the Indonesian learners is higher than the ones used by the native learners.

\subsubsection{Coordination}

Type 4 is about the coordination. There are the sub parts namely (1) Coordinate phrases per clause, (2) Coordinate phrases per T-unit, and (3) Sentence coordination ratio which count the number of T-units per sentence.

\begin{tabular}{|c|c|c|c|c|c|c|}
\hline \multirow{2}{*}{ No } & \multicolumn{2}{|c|}{ CP/C } & \multicolumn{2}{c|}{ CP/T } & \multicolumn{2}{c|}{ T/S } \\
\cline { 2 - 7 } & Indonesian & Native & Indonesian & Native & Indonesian & Native \\
\hline 1 & 0.82 & 0.52917 & 0.99 & 0.7125 & 5.51 & 5.58403 \\
\hline 2 & 0.71 & 0.8125 & 1.06 & 0.97917 & 5.06 & 5.47153 \\
\hline 3 & 0.75 & 1.12222 & 0.96 & 1.52222 & 5.26 & 5.12083 \\
\hline 4 & 0.74 & 0.71042 & 0.93 & 0.89306 & 5.48 & 4.96042 \\
\hline 5 & 0.80 & 0.72361 & 0.98 & 0.93819 & 5.58 & 5.19097 \\
\hline 6 & 0.80 & 0.84861 & 1.06 & 1.06111 & 5.81 & 5.37639 \\
\hline 7 & 0.55 & 0.74653 & 0.71 & 0.93819 & 5.56 & 5.40903 \\
\hline 8 & 0.87 & 0.79792 & 1.16 & 0.96458 & 5.27 & 5.20833 \\
\hline 9 & 0.56 & 0.56111 & 0.86 & 0.67778 & 5.70 & 5.63819 \\
\hline 10 & 0.82 & 0.85 & 1.03 & 1.08194 & 5.19 & 5.19167 \\
\hline 11 & 0.22 & 0.86806 & 0.28 & 1.10069 & 5.59 & 5.22431 \\
\hline 12 & 0.57 & 0.84167 & 0.69 & 1.01597 & 5.46 & 5.58264 \\
\hline 13 & 0.66 & 0.98056 & 0.84 & 1.17361 & 4.98 & 4.93056 \\
\hline 14 & 0.28 & 0.56667 & 0.36 & 0.7125 & 5.89 & 5.52708 \\
\hline 15 & 0.90 & 0.66111 & 1.11 & 0.85764 & 5.06 & 5.68194 \\
\hline
\end{tabular}

*Author(s) Correspondence:

E-mail: murniati@bundamulia.ac.id 


\begin{tabular}{|l|l|c|c|c|c|c|}
\cline { 3 - 7 } 16 & 0.75 & 0.77917 & 0.93 & 0.95486 & 5.23 & 5.61181 \\
\hline 17 & 0.87 & 0.95 & 1.16 & 1.20347 & 5.89 & 5.20833 \\
\hline 18 & 0.83 & 0.83333 & 1.06 & 1.11111 & 5.21 & 5.36944 \\
\hline 19 & 0.66 & 1.06806 & 0.84 & 1.35 & 5.59 & 5.43472 \\
\hline 20 & 0.93 & 0.65139 & 1.18 & 0.81181 & 5.40 & 5.62847 \\
\hline 21 & 0.73 & 0.71597 & 0.92 & 0.90208 & 5.71 & 5.57014 \\
\hline 22 & 0.41 & 0.66111 & 0.53 & 0.81667 & 5.27 & 5.36597 \\
\hline 23 & 0.72 & 0.56667 & 0.93 & 0.68611 & 5.41 & 5.56944 \\
\hline 24 & 0.90 & 0.84861 & 1.24 & 1.06111 & 5.17 & 5.49444 \\
\hline 25 & 0.61 & 1.05694 & 0.94 & 1.33194 & 5.53 & 5.57083 \\
\hline 26 & 0.79 & 0.80764 & 1.05 & 1.02153 & 5.39 & 4.67569 \\
\hline 27 & 0.97 & 0.69444 & 1.35 & 0.83333 & 5.56 & 5.54097 \\
\hline 28 & 1.00 & 0.72708 & 1.19 & 0.91944 & 5.61 & 5.13264 \\
\hline 29 & 0.41 & 0.89861 & 0.57 & 1.14028 & 5.28 & 5.16944 \\
\hline 30 & 0.51 & 0.4125 & 0.69 & 0.57083 & 5.23 & 5.28056 \\
\hline Av & 0.70 & 0.77639 & 0.92 & 0.97812 & 5.43 & 5.35736 \\
\hline
\end{tabular}

Table 4.7. Coordination

As can be seen above, Indonesian learners tend to use more coordinate phrase both per unit and per clause. The number of Tunit in the sentence, however, shows the similar results.

\subsubsection{Particular Structures}

It is divided into (1) Complex nominal per clause, (2) Complex nominal per T-unit, and (3) Verb phrases per T-unit.

\begin{tabular}{|c|c|c|c|c|c|c|}
\hline \multirow{2}{*}{ No } & \multicolumn{2}{|c|}{ CN/C } & \multicolumn{2}{c|}{ CN/T } & \multicolumn{2}{c|}{ VP/T } \\
\cline { 2 - 7 } & Indonesian & Native & Indonesian & Native & Indonesian & Native \\
\hline 1 & 12,688 & 14,190 & 15,325 & 19,103 & 12,468 & 14,744 \\
\hline 2 & 11,705 & 13,723 & 17,458 & 16,538 & 15,763 & 12,949 \\
\hline 3 & 12,581 & 14,444 & 16,250 & 19,589 & 13,472 & 15,068 \\
\hline 4 & 11,600 & 14,545 & 14,500 & 18,286 & 12,833 & 13,286 \\
\hline 5 & 12,188 & 13,750 & 15,000 & 17,838 & 12,308 & 13,514 \\
\hline 6 & 11,263 & 14,778 & 14,861 & 18,472 & 14,028 & 13,333 \\
\hline
\end{tabular}

*Author(s) Correspondence:

E-mail: murniati@bundamulia.ac.id 


\begin{tabular}{|c|c|c|c|c|c|c|}
\hline 7 & 12,247 & 11,828 & 16,029 & 14,865 & 13,971 & 13,649 \\
\hline 8 & 13,409 & 15,287 & 17,879 & 18,472 & 14,242 & 13,333 \\
\hline 9 & 10,714 & 13,232 & 16,438 & 15,976 & 16,712 & 12,805 \\
\hline 10 & 13,118 & 14,082 & 16,486 & 17,922 & 13,243 & 13,766 \\
\hline 11 & 12,766 & 15,096 & 16,216 & 19,146 & 12,838 & 14,756 \\
\hline 12 & 13,402 & 14,545 & 16,049 & 17,561 & 13,210 & 12,805 \\
\hline 13 & 12,738 & 14,235 & 16,212 & 17,042 & 13,333 & 12,113 \\
\hline 14 & 11,224 & 13,265 & 14,103 & 16,667 & 13,462 & 13,333 \\
\hline 15 & 12,903 & 11,143 & 16,000 & 14,444 & 12,800 & 13,580 \\
\hline 16 & 12,651 & 12,857 & 15,672 & 15,750 & 12,985 & 13,000 \\
\hline 17 & 13,482 & 14,316 & 17,976 & 18,133 & 13,452 & 12,667 \\
\hline 18 & 12,717 & 13,100 & 16,250 & 17,467 & 12,917 & 14,267 \\
\hline 19 & 13,474 & 12,857 & 17,297 & 16,250 & 13,784 & 13,472 \\
\hline 20 & 12,417 & 13,438 & 15,851 & 16,753 & 14,149 & 12,468 \\
\hline 21 & 12,788 & 12,577 & 16,024 & 15,844 & 13,614 & 13,117 \\
\hline 22 & 12,118 & 15,952 & 15,606 & 19,706 & 14,242 & 13,529 \\
\hline 23 & 13,766 & 13,571 & 17,667 & 16,420 & 15,000 & 12,222 \\
\hline 24 & 12,581 & 14,889 & 17,463 & 18,611 & 14,478 & 12,917 \\
\hline 25 & 12,895 & 12,935 & 19,865 & 16,301 & 15,811 & 13,288 \\
\hline 26 & 13,093 & 15,465 & 17,397 & 19,559 & 14,521 & 12,941 \\
\hline 27 & 13,300 & 12,778 & 18,472 & 15,333 & 13,889 & 13,333 \\
\hline 28 & 11,000 & 12,674 & 13,026 & 16,029 & 13,553 & 13,529 \\
\hline 29 & 12,277 & 14,235 & 16,986 & 18,060 & 14,795 & 13,582 \\
\hline 30 & 12,842 & 12,277 & 17,429 & 16,986 & 14,571 & 14,795 \\
\hline Av & $12,531.57$ & $13,735.5$ & $16,392.90$ & $17,304.1$ & $13,881.47$ & 13,405 \\
\hline
\end{tabular}

Table 4.8. Particular structures

Unlike the previous results, it can be seen that the native learners tend to use more complex nominal both per clause and per TUnits. The Indonesian learners, on the other hands, use more verb phrases per unit.

*Author(s) Correspondence:

E-mail: murniati@bundamulia.ac.id 


\section{CONCLUSIONS AND SUGGESTIONS}

\subsection{Conclusions}

In general, it can be concluded that based on the syntactic structure, it can be seen that the Indonesian learners write longer abstracts with more sentences than the native speakers. The Indonesian learners' abstracts can also be seen directly that it is more complex with more dependent clauses used. However, when we observe its syntactic complexity, the results are a bit different. It can be seen in the table below.

\begin{tabular}{|c|c|c|c|}
\hline No & Type & Indonesian Learners & Native learners \\
\hline \multicolumn{4}{|c|}{ Type 1: Length of production unit } \\
\hline 1 & Mean length of clause & Lower & Higher \\
\hline 2 & $\begin{array}{l}\text { Mean length of } \\
\text { sentence }\end{array}$ & Lower & Higher \\
\hline 3 & Mean length of T-unit & Lower & Higher \\
\hline \multicolumn{4}{|c|}{ Type 2: Sentence complexity } \\
\hline 4 & $\begin{array}{l}\text { Sentence complexity } \\
\text { ratio }\end{array}$ & Higher & Lower \\
\hline \multicolumn{4}{|c|}{ Type 3: Subordination } \\
\hline 5 & $\begin{array}{l}\text { T-unit complexity } \\
\text { ratio }\end{array}$ & Higher & Lower \\
\hline 6 & Complex T-unit ratio & Higher & Lower \\
\hline 7 & Dependent clause ratio & Higher & Lower \\
\hline 8 & $\begin{array}{l}\text { Dependent clauses per } \\
\text { T-unit }\end{array}$ & Higher & Lower \\
\hline \multicolumn{4}{|c|}{ Type 4: Coordination } \\
\hline 9 & $\begin{array}{l}\text { Coordinate phrases per } \\
\text { clause }\end{array}$ & Similar & Similar \\
\hline 10 & $\begin{array}{l}\text { Coordinate phrases per } \\
\text { T-unit }\end{array}$ & Similar & Similar \\
\hline 11 & $\begin{array}{l}\text { Sentence coordination } \\
\text { ratio }\end{array}$ & Similar & Similar \\
\hline \multicolumn{4}{|c|}{ Type 5: Particular structures } \\
\hline 12 & $\begin{array}{l}\text { Complex nominals per } \\
\text { clause }\end{array}$ & Lower & Higher \\
\hline 13 & $\begin{array}{l}\text { Complex nominals per } \\
\text { T-unit }\end{array}$ & Lower & Higher \\
\hline 14 & $\begin{array}{l}\text { Verb phrases per T- } \\
\text { unit }\end{array}$ & Higher & Lower \\
\hline
\end{tabular}

Table 5.1. The overall results of syntactic complexity

The overall results reveal some academic writing characteristics of the Indonesian learners. First, it is stated that they tend to write more complex sentences. There are several reasons why their writings are considered as complex. One reason is unfortunately due to grammatical errors. For example, one student has written " Stowe was writing about her experience which there was discrimination toward Niger". While syntactically analyzed, that ungrammatical sentence has longer analysis which resulted to

*Author(s) Correspondence:

E-mail: murniati@bundamulia.ac.id 
a more complex sentence. Another reason is that the lexis used are sometimes ambiguous, such as "values is collection of values ..." In analyzing that sentence, those two lexis "value" need longer analysis.

The next Indonesia learners' characteristics while writing abstracts is that they tend to write by using subordination. They like to add more explanation by adding dependent clause, such as in "... about slang especially that the researcher found in the movie". That dependent clause is grammatically correct but not really effective. In addition, those Indonesian learners also tend to use participial phrases in the abstracts, as a result, the subordination results are higher and the sentence complexity is also higher.

Last but not least, the Indonesian learners use more various tenses in the abstracts. When they use past continuous, such as in "Stowe was writing about ...", the verb phrase should result in longer and more complex sentence, clause, and unit. Next, they also like to add adverb to the verb, such as in "The researcher initially conducted ..." It also resulted in longer production of sentences, clause, and unit.

Moving to the characteristics of the abstracts written down by native speakers, first, they tend to write complex nominal. For example, it is found out in one of the abstracts "The Russian novelist Fryudor Dustoesky ...". Those words refers to one subject which is described in complex nominal. The next characteristics is that they tend to add more explanation in each sentence by adding commas, such as in "Through research on his writing style, biography, and a close reading of his novel Notes from the underground I am exploring the impact of his most famous outcast, the Underground man, on counterculture writers in America during the great subculture upsurge of the 1950s and 60s. That addition comma is one of the reasons why the numbers of mean length of the sentences, T-Unit and clause is considered as high in the abstracts written down by the native speakers.

\footnotetext{
*Author(s) Correspondence:

E-mail: murniati@bundamulia.ac.id
}

\subsection{Suggestions}

After this research has completely been conducted and the results have all been discussed, there are suggestions for both this research and for a better future research in this field. First of all, ideally a previous research regarding lexical complexity should be conducted earlier. It is expected that the bias regarding the lexical can be avoided. Next, it is also recommended to group the learners into low, middle, and high proficiency. As a result, the topic should only cover Indonesian learners. Finally, the syntactic complexity analyzer can be broadened by using another analyzer.

\section{REFERENCES}

Bardovi-Harlig, K. (1992). A second look at T-unit analysis: Reconsidering the sentence. TESOL Quarterly, 26(2), 390395.

Biber, D., \& Gray, B. (2015). Grammatical complexity in academic English: Linguistic change in writing. Cambridge: Cambridge University Press.

Biber, D., Johansson, S., Leech, G., Conrad, S., \& Finegan, E. (1999). Longman grammar of spoken and written English. Harlow: Pearson Education

Colombi, M. C. (2002). Academic language development in Latino students' writing in Spanish. In M. J. Schleppegrell \& M. C. Colombi (Eds.). Developing advanced literacy in first and second languages: Meaning with power (pp. 67-86). New Jersey: Lawrence Erlbaum Associates.

Crystal, D. (2003). English as a global language. Cambridge: Cambridge University Press.

Fang, Z. \& Schleppegrell, M. J. (2008). Reading in secondary content areas: A language-based pedagogy. Ann Arbor: The University of Michigan Press. 
Fang, Z., Schleppegrell, M. J., \& Cox, B. E. (2006). Understanding the language demands of schooling: Nouns in academic registers. Journal of Literacy Research, 38(3), 247-273.

Hunston, S. (2005). Conflicts and consensus: Construing opposition in applied linguistics. In E. Tognini-Bonelli \& G. Del Lungo Camiciotti (Eds.). Strategies in academic discourse (pp. 1-15). Amsterdam: John Benjamins.

Kachru, B. B. (1989). Teaching world Englishes. Indian Journal of Applied Linguistics, 15(1), 85-95.

Lu, X. \& Ai, H. (2015). Syntactic complexity in college-level English writing: Differences among writers with diverse L1 backgrounds. Journal of Second Language Writing, 29, 16-27.

Michigan State University. (2017, December 18). Sample abstracts - Social sciences. Retrieved from https://urca.msu.edu/resources/sampleabstract-social-science.

School of the Art Institute of Chicago. (2017, December 18). SAIC thesis repository. Retrieved from http://digitallibraries.saic.edu/cdm/compoundobject/ collection/thesis/id/36325/rec/6

Seifoori, Z., \& Fattahi, J. (2014). The comparison of the method section of applied linguistics articles written by native and Iranian writers in terms of grammatical complexity and clause types. Procedia-Social and Behavioral Sciences, 98, 1698-1705.

Tapper, M. (2005). Connectives in advanced Swedish EFL learners' written Englishpreliminary results. The Department of English: Working Papers in English Linguistics, 5, 116-144.

The University of Adelaide. (2017, December 18). Writing an abstract. Retrieved from https://www.adelaide.edu.au/writingcent re/docs/learningguidewritinganabstract.pdf.

University of Montana. (2017, December 18). Sample abstracts. Retrieved from http://www.umt.edu/ugresearch/umcur/s ample_abstracts.php.

University of Massachusets. (2017, December 18). Sample theses. Retrieved from https://www.umass.edu/english/sampletheses.

University of Notre Dame. (2017, December 18). Thesis abstracts. Retrieved from https://english.nd.edu/undergraduate/cre ative-writing-honorsconcentration/2014-thesis/.

*Author(s) Correspondence:

E-mail: murniati@bundamulia.ac.id 